\title{
A homonimy in Psyllidae (Homoptera): a new name for Neopelma Burckhardt ${ }^{1}$
}

\author{
Fernando Costa Straube ${ }^{2}$ \\ Michel Miretzki ${ }^{2,3}$
}

\begin{abstract}
Burckhardtia nom. nov. is proposed for Neopelma Burckhardt, 1987 (Psyllidae, Homoptera), preoccupied by Neopelma Sclater, 1860 (Pipridae, Aves). KEY WORDS. Homoptera, Psyllidae, Neopelma, Burckhardtia, homonimy, Aves
\end{abstract}

\section{Burckhardtia nom. nov.}

Neopelma Burckhardt, 1987: 330 (type-species: Neopelma baccharidis Burckhardt, 1987: 332, by original designation), non Neopelma Sclater, 1860: 467.

BURCKHARDT (1987) described the genus Neopelma, a jumping plant lice of the family Psyllidae, for two proposed new species from several localities of South America (Chile, Brazil, Argentina and Paraguay).

However, this name is preoccupied by Neopelma Sclater, 1860 a genus including five bird species of the neotropical family Pipridae from rainforests of Atlantic and Amazonic regions (SNOw 1979; WHITNEY et al. 1995). Therefore, Burckhardtia nom. nov. is here proposed to substitute Neopelma Burckhardt, 1987. The nominal genus is in honor to the entomologist Daniel Burckhardt.

ACKNOWLEDGEMENTS. To Rodney Cavichioli, Paulo H. Labiak and Ana L.C. Prudente for the warning and providing literature.

\section{REFERENCES}

BURCKHARDT, D. 1987. Jumping plant lice (Homoptera: Psylloidea) of the temperate neotropical region. Part 1: Psyllidae (subfamilies Aphalarinae, Rhinocolinae and Aphalaroidinae). Zool. Journ. Linnean Soc. 89: 299-392.

Sclater, P.L. 1860. Characters of ten new species of American birds. Proc. Zool. Soc. London 28: 461-467.

SNOw, D. 1979. Pipridae, p.245-280. In: M.A. TRAYLOR JR. (Ed.) Peters' Checklist of the birds of the world. Cambridge, Museum of Comparative Zoology.

WHITNEY, B.M.; J.F. PACHECO \& R. PARRINI. 1995. Two species of Neopelma in southeastern Brazil and diversification within the Neopelma/Tyranneutes complex: implications of the subspecies concept for conservation (Passeriformes: Tyrannidae). Ararajuba 3: 43-53.

Recebido em 26.XI.1998; aceito em 07.X.1999.

1) Contribuição número 1151 do Departamento de Zoologia, Universidade Federal do Paraná.

2) Mülleriana, Sociedade Fritz Müller de Ciências Naturais. Caixa Postal 1644, 80001-970 Curitiba, Paraná, Brasil.

E-mail: mulleriana@milenio.com.br

3) Museu de História Natural Capão da Imbuia, Prefeitura Municipal de Curitiba. Rua Professor Benedito Conceição 407, 82810-080 Curitiba, Paraná, Brasil. 